Diese Reaktion konnte durch DCMU nicht gehemmt werden und war auch in einer Chloroplasten-Präparation möglich, die keine $\mathrm{Hill}$-Reaktion mehr durchführen konnte.

Unglücklicherweise wurden die Namen zweier Prozesse - oxydative Photophosphorylierung und $\mathrm{O}_{2}$-katalysierte Photophosphorylierung - öfters nicht klar getrennt. Eine Arbeit von KrogmanN ${ }^{15}$ über oxydative Photophosphorylierung befaßt sich tatsächlich mit $\mathrm{O}_{2}$-katalysierter Photophosphorylierung.

Wir glauben, daß die Ergebnisse von Krogmann 25 als eine cyclische Photophosphorylierung mit Indophenol als Cofaktor zu erklären sind, nachdem das Indophenol - da die Hill-Reaktion unter Krogmanss Bedingungen nicht ablaufen konnte chemisch durch Ascorbinsäure oder enzymatisch durch DPNH reduziert worden war. Wie unsere Versuche zeigen, ist zur ATP-Bildung mit Dichlorphenolindophenol als Cofaktor kein $\mathrm{O}_{2}$ und zur Reduktion des Indophenols bei Anwesenheit von DCMU nur eine dem Indophenol äquivalente Menge DPNH, Dithionit oder Ascorbinsäure notwendig. Es zeigt sich keine Proportionalität zwischen Reduktionsmittel und gebildetem ATP. In Luft sind allerdings mehr als äquivalente Mengen Reduktionsmittel nötig, da die chlorophyll-sensibilisierte Photooxydation kompensiert werden muß. Auch in der Arbeit von KrogmanN ${ }^{25}$ steht die $\mathrm{O}_{2}$-Aufnahme in keinem Zusammenhang mit der DPNH-Oxydation. Zweifel an der Interpretation der Ergebnisse im
Sinne einer oxydativen Photophosphorylierung und damit einer neuartigen Reaktion sind bereits von ARnon ${ }^{12}$ und JAGENDORF ${ }^{13}$ geäußert worden.

Die Indophenole stellen somit eine neue Klasse von Cofaktoren der cyclischen Photophosphorylierung dar. Wegen ihres höheren Redoxpotentials gegenüber dem der Vitamin K-Derivate und anderer bisher bekannter Cofaktoren, sollte man annehmen, daß diese Indophenole an einer anderen Stelle des cyclischen Elektronentransportes eingreifen, etwa beim Cytochrom $\mathrm{f}$.

Mit dieser Vorstellung sind die Ergebnisse von JAGENDORF $^{23}$ und von VERNON ${ }^{24}$ über die Reduktion von TPN durch Indophenol/Ascorbinsäure gut vereinbar. Sie erklären jedoch nicht, weshalb die Reduktion der Indophenole nicht mit einer ATP-Bildung gekoppelt ist ${ }^{22}$. Bei unseren Versuchen zeigte sich jedoch deutlich, daß immer dann, wenn im Gefäß noch die blaue Farbe des oxydierten Indophenols zu erkennen war, keine Phosphorylierung stattfand. Man könnte also an eine Hemmung durch den oxydierten Farbstoff denken. Aus der Entkopplung der Reduktion der Indophenole hat Arnon kürzlich auf eine zweite nicht gekoppelte Lichtreaktion geschlossen ${ }^{26}$.

Wir sind Herrn Professor Dr. F. Weygand für seine Unterstützung und der Deutschen Forschungs g e m e in s ch a f t für Sachbeihilfen dankbar.

26 M. Losada, F. R. Whatley u. D. I. Arnon, Nature [London] 190, 606 [1961].

\title{
Die Identifizierung zweier im Tenebriokot und in Hefe vorkommender Substanzen mit Juvenilhormonwirkung
}

\author{
Von Peter Schmialek \\ Aus dem Physiol.-chemischen Institut der Freien Universität Berlin \\ (Direktor: Prof. Dr. Dr. E. Sснӥтte) \\ (Z. Naturforschg. 16 b, 461-464 [1961] ; eingegangen am 6. Februar 1961)
}

\begin{abstract}
Aus Hefe und Tenebriokot wurde durch chromatographische Reinigung eine Fraktion mit starker Juvenilhormonwirkung erhalten. Das chemische und chromatographische Verhalten der Aktivität sprach dafür, daß die hormonale Wirksamkeit hauptsächlich auf dem Gehalt an Farnesol und Farnesal beruhte. Synthetischer Farnesol und Farnesal rufen nach Injektion in Insekten Corpus allatumHormon-Wirkungen hervor.
\end{abstract}

Das von den Corpora allata der Insekten sezernierte Juvenilhormon (Corpus allatum-Hormon, Neotenin) hält, wie $\mathrm{W}_{\text {IgGlesworth }}{ }^{1}$ zeigte, den Lar-

1 V. B. WIGglesworth, Quart. J. micr. Sci. 77, 191 [1934]. vencharakter des wachsenden Insekts aufrecht. Die ersten Extrakte mit Hormonwirkung erhielt WILLIAMs $^{2}$ aus Hinterleibern von Wildseidenspinnern.

2 C. M. Williams, Nature [London] 178, 212 [1956]. 
Später wurde Juvenilhormon-Aktivität in zahlreichen Avertebraten ${ }^{3}$, und sogar in Rindernebennieren ${ }^{4}$ nachgewiesen. Im Tenebriokot wurde sie von Karlson und Schmialek erstmals festgestellt ${ }^{5}$. Es war das Ziel der vorliegenden Arbeit, die Struktur der aktiven Verbindung aufzuklären.

\section{Anreicherung der Aktivität}

Aus $80 \mathrm{~kg}$ Mehlwurmkot wurde nach mehrfacher Extraktion mit Methanol-Benzol und anschließender Absorptionschromatographie $\left(\mathrm{Al}_{2} \mathrm{O}_{3}\right.$ Woelm, neutral, Akt. V, Elutionsmittel Chloroform : Äthanol $9: 1) 4 \mathrm{~g}$ einer braunen öligen Fraktion mit $40 \%$ Hormonaktivität * erhalten.

Die weitere Anreicherung ergab nach Dünnschichtchromatographie (Kieselgel G Merck, mit 15\% Wasser beladen, Laufphase 15\% Essigester, 85\% Benzin vom Sdp. $50-70^{\circ} \mathrm{C}$, Laufstrecke $\left.40 \mathrm{~cm}\right) 60 \mathrm{mg}$ eines hellgelben Öles von der Aktivität 100 Prozent. Diese Fraktion wurde in Benzin gelöst und mehrfach zur Entfernung der aus dem Kieselgel eluierten Verunreinigungen mit 20-proz. Methanol ausgeschüttelt.

\section{Reaktionen zur Identifizierung des chemischen Charakters der aktiven Substanz}

$40 \mathrm{mg}$ Rückstand der lipophilen Phase der Verteilung zwischen 20-proz. Methanol und Benzin wurden eingesetzt, um das chemische Verhalten der wirksamen Substanz zu untersuchen.

Da der benutzte Test bei Einsatz kleinster Mengen nicht sehr genau ist, konnten keine quantitativen Aussagen über die Abnahme oder das Gleichbleiben der Aktivität gemacht werden. Ein völliger Aktivitätsverlust trat nach 10-stdg. Schütteln mit 1-proz. wäßrig-methanolischer Salzsäure ein. Eine geringe Wirkungseinbuße fand sich nach alkalischer Verseifung, bei Hydrierung mit $\mathrm{LiAlH}_{4}$, beim Versuch der Veresterung mit 3.5Dinitrobenzoylchlorid oder der Bildung eines 2.4-Dinitrophenylhydrazons.

Nach Oxydation mit frisch gefälltem Braunstein blieb die Aktivität erhalten, verschwand aber bei der Darstellung der Semicarbazone des Oxydationsansatzes zum größten Teil, während ohne Oxydation die Semicarbazonbildung zu keinem deutlichen Aktivitätsver-

${ }^{3}$ H. A. Schneiderman u. L. I. Gilbert, The Chemistry and Physiology of Insect Growth Hormones, in: Cell Organismen and Milieu, 17. Growth Symposion. Edited by D. RuD Nick, Donald Press, New York 1959, S. 157.

4 L. I. Gilbert u. H. A. Schneiderman, Science [Washinton] 128, 844 [1958].

5 P. Karlson u. P. Schmialek, Z. Naturforschg. 14 b, 821 [1959]. lust führte. Nach Spaltung der Semicarbazone des Oxydationsansatzes trat die biologische Wirkung z. T. wieder auf und wurde durch Reduktion mit $\mathrm{LiAlH}_{4}$ zerstört, während die Reduktion der Ausgangslösung mit Hydrid nur zu einem geringen Aktivitätsverlust führte.

Die hormonal wirksame Substanz mußte also ein primärer oder sekundärer Allylalkohol sein, dessen Carbonylanaloges ebenfalls Hormonwirkung besitzt.

Papierchromatographische

Identifizierung der aktiven Substanz und ihrer Derivate

Die durch Oxydation mit Braunstein erhaltene Carbonylverbindung wurde in das Semicarbazon übergeführt, nach Verdünnen des methanolischen Reaktionsansatzes mit Wasser die Trübung in der Kälte abzentrifugiert und das Sediment chromatographiert. (Papier SS $2043 \mathrm{~b}$, System Benzin : Methanol : Benzol : Wasser $=70: 50: 20: 2$ ). Der $R_{f}$-Wert betrug 0,6 .

Das Semicarbazon ließ sich direkt in das 2.4-Dinitrophenylhydrazon umwandeln, das einen $R_{f}$-Wert von 0,3 besaß. (Papier $2043 \mathrm{~b}$ mit Siliconöl Bayer M 300 in Cyclohexan getränkt, System mit umgekehrten Phasen, Methanol : Wasser : Benzin vom Sdp. $100-140^{\circ} \mathrm{C}=$ $95: 5: 150)$.

Der $R_{f}$-Wert des freien Alkohols betrug 0,4 (Papier 2043 b mit Siliconöl Bayer M 1000 in Cyclohexan getränkt, System mit umgekehrten Phasen, Methanol : Wasser : Benzin vom Sdp. $100-140{ }^{\circ} \mathrm{C}=9: 1: 5$ ).

Der Vergleich der $R_{f}$-Werte des biologisch aktiven Alkohols und seiner Umwandlungsprodukte mit denen anderer Verbindungen lie $\beta$ vermuten, da $ß$ die Substanz aus Mehlwurmkot, die Juvenilhormon-Aktivität besitzt, ein primärer C 15 Allylalkohol sei.

Farnesol und seine Derivate zeigten die gleichen $R_{f}$-Werte wie die entsprechenden Derivate der hormonal wirksamen Verbindung.

Nachdem sich herausgestellt hatte, daß Farnesol in den aktiven Fraktionen aus Tenebriokot vorhanden war, wurden die Randfraktionen der Dünnschichtchromatographie nochmals getrennt und auf der Platte eine Verbindung vom $R_{f}$-Wert des Farnesals mit $o, o$-Dianisidin angefärbt. Auch papierchromatographisch konnte Farnesal als Semicarbazon identifiziert werden. Ob Farnesal während des Aufarbeitungsganges aus Farnesol entstanden war, wurde nicht untersucht.

Aus $12 \mathrm{~kg}$ Hefe wurde nach Autolyse der Zellen eine Fraktion erhalten, die im Tenebriotest $80 \%$ Aktivität zeigte und in der nach Oxydation mit Braunstein und Semicarbazonbildung eine geringe Menge Farnesal-

\footnotetext{
* Der Hormongehalt der einzelnen Fraktionen wurde nach $\mathrm{W}_{\text {IgGLesworth }}{ }^{6}$ durch Einimpfen des Extraktes in die Haut von Mehlwurmpuppen bestimmt. Als $100 \%$ aktiv wurde eine Fraktion bezeichnet, die in 10-proz. Äthylenglykolmonomethyläther bei 9 von 10 Käfern auch entfernt von der Punktionsstelle Puppenhautbezirke entstehen ließ. Weniger aktive Extrakte führten nur zu einer lokalen Bildung des Puppeninteguments am Ort der Injektion.

6 V. B. Wigglesworth, J. Insect. Physiol. 2. 73 [1958].
} 
semicarbazon papierchromatographisch nachgewiesen werden konnte.

Farnesol (aus Blütenöl isoliert oder aus Nerolidol synthetisiert ${ }^{7}$ ) und Farnesal (aus Nerolidol dargestellt ${ }^{8}$ ), besaßen im Tenebriotest in 10-proz. Äthylenglykolmonomethyläther $100 \%$ Corpus allatum Hormonwirkung.

\section{Diskussion}

Der Nachweis, daß Farnesol und Farnesal für die Juvenilhormonwirkung von Extrakten aus Hefe und Mehlwurmkot ganz oder z. T. verantwortlich sind, wirft die Frage auf, ob es sich bei diesen beiden Verbindungen um das eigentliche Corpus allatumHormon handelt, auch wenn die durch sie bei Insekten hervorgerufenen Veränderungen denen gleichen, die durch angereicherte Extrakte von Samia cynthia ausgelöst werden.

StellwaAg-Kittler ${ }^{9}$ nahm an, daß nicht die Retention des Juvenilhormons, sondern das Zurückbleiben von irgendwelchen Giften die Verpuppung von Tenebriolarven, bei denen die Exkretion unterbunden wurde, verhindert. Ein solches Gift mit Corpus allatum-Hormonwirkung könnte Farnesol sein, der sich in den meisten Pflanzen und damit in der Nahrung vieler Insekten findet.

In der vorliegenden Untersuchung konnte nicht geklärt werden, ob Farnesol und Farnesal die einzigen Substanzen im Mehlwurmkot und in Hefe sind, die Juvenilhormonwirkung zeigen. Farnesolhomologe und ihre Derivate kommen in fast allen Pflanzen vor. Lynen ${ }^{10}$ fand Anhaltspunkte für die Bildung höherer Isoprenoidalkohole auch in Hefe.

Beim Vergleich der Hormonaktivität einer Verdünnungsreihe von Farnesol in Olivenöl mit dem Farnesolgehalt und der hormonalen Wirkung der Fraktion aus Tenebriokot zeigte es sich, daß letztere einen um etwa 50\% stärkeren Effekt hervorrief, als ihrem Farnesolgehalt entsprach. Diese Diskrepanz spricht aber nicht unbedingt für das Vorhandensein einer weiteren Substanz mit Corpus allatum-Hormonwirkung, da die Aktivität auch von dem benutzten Lösungsmittel abhängt. Farnesol ohne Lösungsmittel besitzt eine Aktivität von $26 \%$, während dieser Alkohol in 10-proz. äthanolischer und 5-proz. Äthylenglykolmonomethyläther-Lösung 100\% aktiv ist.

7 L. Ruzicka, Helv. chim. Acta 6, 492 [1923].

8 M. Stoll u. A. Commarmont, Helv. chim. Acta 32, 1356 [1949].

9 F. Stellwaag-Kittler, Biol. Zbl. 73, 12 [1954].
Der Firma Claus, Limburgerhof, danke ich für die Ủberlassung größerer Mengen Mehlwurmabgänge. Herr Direktor Dr. Steinhofer von der Badischen Anilin. und Sodafabrik, Ludwigshafen, und Herr Dr. Schnell von den Farbenfabriken Bayer, Werk Uerdingen, stellten freundlicherweise die benötigten Lösungsmittel zur Verfügung.

\section{Appendix \\ Some effects of farnesolin other insects: preliminary experiments}

By V. B. Wigglesworth

from the Department of Zoology, University of Cambridge

The Tenebrio test ${ }^{6}$ is convenient for rapid comparisons of the hormonal activity of extracts; but it seemed desirable to make certain that farnesol would also bring about the more elaborate morphological changes in whole insects that are produced by the juvenile hormone. A purified sample of farnesol prepared by Dr. P. Schmialek was used in the following experiments.

When tested on Rhodnius this material proved highly active. 5th-stage larvae to which a thin film of farnesol was applied on the surface of the intact cuticle developed into extra or 6th-stage larvae with the same characters as those receiving implants of corpora allata ${ }^{11}$. When fed again, these larvae failed to moult: presumably the active substance had not reached the thoracic glands; only the surface of the body retained its larval characters. But when a single abdominal tergite of the larvae was subjected to micro-abrasion by painting with a suspension of alumina ${ }^{6}$ before the farnesol was applied, so that rather more material could enter the insect, they not only moulted into 6th-stage larvae, but after another meal they moulted again and (in the absence of further treatment) developed adult characters. There had been a real delay in metamorphosis.

Preliminary experiments have also demonstrated a juvenile hormone effect of farnesol in the milkweed bug Oncopeltus fasciatus, in the bed-bug Cimex lectularius and in the pupating larva of the meal moth Ephestia kühniella.

The corpus allatum in the adult Rhodnius secretes a hormone that is necessary for yolk formation

10 F. Lynen, Vortrag vor dem Ortsverband der G. D. CH. Berlin, Berlin November 1960.

11 V. B. Wigglesworth, Quart. J. micr. Sci. 79, 91 [1936]. 
in the developing eggs ${ }^{11}$. Since this same effect is produced in adult females joined in parabiosis to 4th-stage larvae which retain the corpus allatum, it was later suggested that the juvenile hormone and the yolk forming hormone were one and the same substance ${ }^{12}$. Lüscher and SPringhetri ${ }^{13}$ working with the termite Kalotermes and SäGESSER ${ }^{14}$ using the cockroach Leucophaea have concluded that there is probably a distinct "gonadotropic hormone" secreted in the adult insect. When farnesol is applied to the surface of the cuticle of adult female Rhodnius decapitated within twenty-four hours after feeding, they rapidly digest their blood meal and pro-

12 V. B. Wigglesworth, J. exp. Biol. 25, 1 [1948].

13 M. Lüscher and A. Springhetti, J. Ins. Physiol. 5, 190 [1960]. duce abundant ripe eggs in their ovaries; whereas decapitated controls digest their meal extremely slowly and develop no ripe eggs.

It will be of interest to learn the relation of farnesol to the natural hormone of the corpus allatum. "It has long been realized that the juvenile hormone in insects is merely controlling the manifestation of certain genetically determined characters in the growing epidermal cells. It would be by no means impossible for a variety of chemical substances to exert such an effect - just as a wide variety of chemicals can exert an 'anti-bar' effect in bar-eyed mutants of Drosophila ${ }^{15}$."

14 H. Sägesser, J. Ins. Physiol. 5, 264 [1960].

15 V. B. Wigglesworth, Symposium on the ontogenetic development of insects. Prague 1959 (in the press).

\title{
Zeitlich abklingende Vorgänge in der Wirkungskette zwischen Reiz und Erregung (Versuche an abdominalen Streckreceptoren dekapoder Krebse).
}

\author{
Von Lotte Wender und D. Burkhardt * \\ Aus dem Zoologischen Institut der Universität München \\ (Z. Naturforschg. 16 b, $464-469$ [1961] ; eingegangen am 25. Januar 1961)
}

\begin{abstract}
The crayfish stretch receptors show a characteristic pattern of excitation: after a sudden stretch the sensory discharge increases rapidly and then decays to a new steady state level. This decrease, commonly called adaptation, is referred to in the present work as "decay of excitation". Stimulating the receptor organ with a constant load or a constant lengthening reveals that there are at least two factors responsible for the decay of excitation, i. e. the visco-elastic properties of the receptor muscle and the accomodation of the sensory nerve cell.
\end{abstract}

Die Muskelspindeln der Wirbeltiere und die segmentalen Streckreceptoren der Arthropoden sind einander morphologisch ähnlich und zeigen ähnliche Entladungsmuster: Parallel zur Skelettmuskulatur liegen dünne Muskelbündel, die in ihrer Mittelregion sensibel innerviert sind. Nach einer plötzlichen Dehnung erreicht die Entladungsfrequenz nach anfänglichem Überschießen in einem asymptotisch abklingenden Verlauf das der stärkeren Dehnung entsprechende höhere Niveau. Diese meist Adaptation genannte Erscheinung soll in Anlehnung an eine frühere Arbeit ${ }^{1}$ als Erregungsabfall bezeichnet werden. Als Ursachen dieses Erregungsabfalles können meh-

\footnotetext{
* Die Untersuchungen wurden von der D e u t s chen Fors chungs geme in s chaf t unterstützt.

1 D. Burkhardt, Ergebn. Biol. 22, 226 [1960].

2 St. W. Kuffler, J. Neurophysiol. 17, 558 [1954].

3 E. Florey, Z. Naturforschg. 11 b, 504 [1956].

${ }^{4}$ E. Florey, J. gen. Physiol. 40, 533 [1957].
}

rere Vorgänge in Betracht gezogen werden: 1. Die passiv-mechanischen Eigenschaften der in Serie mit den sensiblen Endigungen liegenden Receptormuskeln könnten den Reiz auf seinem Wege zu den sensiblen Endigungen verformen. 2. Selbst bei konstanter Einwirkung des Reizes auf die sensible Region könnten die Primärvorgänge im Receptor zeitlich abklingen. 3. Dasselbe könnte auch für sekundäre Mechanismen gelten, wie für die Übersetzung langsamer Receptorpotentiale in Impulse des afferenten Nerven (Akkommodation). Verschiedene Untersuchungen an den Streckreceptoren des Flußkrebses ${ }^{2-7}$ weisen darauf hin, daß möglicherweise mehrere die-

\footnotetext{
5 C. Eyzaguirre u. St. W. Kuffler, J. gen. Physiol. 39, 87 [19.5.5].

6 C. Eyzaguirre u. St. W. Kuffler, J. gen. Physiol. 39, 121 [1955].

7 D. Burkhardt, Biol. Zbl. 78, 22 [1959].
} 